\title{
Studi Literatur Faktor yang Mempengaruhi Implementasi E-Budgeting dalam Sektor Publik
}

\author{
Faiz Marwan Prayoga
}

Program Studi Akuntansi, Fakultas Ekonomi dan Bisnis, Universitas Pembangunan Nasional "Veteran” Jawa Timur Email: fmarwan65@gmail.com

Indrawati Yuhertiana

Program Studi Akuntansi, Fakultas Ekonomi dan Bisnis, Universitas Pembangunan Nasional “Veteran” Jawa Timur Email: yuhertiana@upnjatim.ac.id

\begin{abstract}
This study aimed to describe the influential factors on the implementation of e-budgeting as part of the phenomenon of public sector accounting reform in Indonesia as the manifestation of transparency in public sector services. This study used a literature review method to identify, evaluate, and interpret numbers of existing relevant research to a particular field or topic. In the literature review method, there were three main stages namely planning, conducting, and reporting the reviews. The literatures were determined by selecting articles from several academic databases. The increasing number of corruption cases that had been increasingly significant in Indonesia demanded the government to find reliable solutions to address the problems. The application of ebudgeting in budget management could create transparent and reliable public sector services. The results indicated that the bureaucratic structure, resources, communication, and disposition had an important influence on the implementation of e-budgeting.
\end{abstract}

Keywords: Accounting Reform, Transparency, E-Government, E-Budgeting.

\begin{abstract}
Abstrak
Studi ini bertujuan untuk mendeskripsikan faktor-faktor yang mempengaruhi implementasi e-budgeting sebagai bagian dari fenomena reformasi akuntansi sektor publik di Indonesia sebagai perwujudan transparansi terhadap pelayanan sektor publik. Penelitian ini menggunakan metode tinjauan literatur yang merupakan cara untuk mengidentifikasi, mengevaluasi, dan menafsirkan penelitian yang telah tersedia dan relevan dengan bidang atau topik tertentu. Dalam metode tinjauan literatur dibagi menjadi 3 tahap utama yaitu planning (perencanaan), conducting (melakukan review) dan reporting (pelaporan). Pencarian literatur dalam penelitian ini dimulai dengan memilih artikel dari beberapa database akademik. Peningkatan kasus korupsi yang semakin signifikan di Indonesia, menciptakan tuntutan bagi pemerintah agar menemukan solusi yang handal dalam mencegah praktik kotor tersebut. Penerapan teknologi $e$ budgeting dalam pengelolaan anggaran dapat mewujudkan pelayanan sektor publik yang transparan dan handal. Hasil dari penelitian ini menyatakan bahwa struktur birokrasi, sumber daya, komunikasi dan disposisi memiliki pengaruh penting dalam implementasi e-budgeting.
\end{abstract}

Kata Kunci: Reformasi Akuntansi, Transparansi, E-Government, E-Budgeting.

\section{PENDAHULUAN}

Krisis yang dialami Indonesia saat tahun 1998 berdampak besar terhadap perekonomian nasional. Terjadinya krisis mata uang pada saat itu membuktikan ketidakefektifan sistem pengelolaan keuangan di sektor publik di Indonesia (Prabowo dkk., 2018). Hal ini menandakan keadaan dimana diperlukannya pembaruan kebijakan demi terciptanya keadaan yang ideal kembali. Kondisi tersebut menimbulkan beberapa tuntutan kuat dari berbagai kalangan masyarakat kepada pemerintah agar segera melakukan reformasi dalam penyelenggaran kehidupan berbangsa dan bernegara. Di Indonesia, kebutuhan dan juga kepentingan dasar tiap-

Article history: Received,27 Januari 2021; Resivised, 02 Mei 2021; Accepted, 06 Mei 2021.

Corresponding author(s): Faiz Marwan Prayoga, Email: fmarwan65@gmail.com

To cite this article: Prayoga, F. M., \& Yuhertiana, I. (2021). Studi Literatur Faktor yang Mempengaruhi Implementasi E-Budgeting dalam Sektor Publik. JPSI ( Journal of Public Sector Innovations ), 05(2), 68-79. https://doi.org/10.26740/jpsi.v5n2.p68-79 
tiap warga negara perlu dipenuhi sesuai dengan amanat UUD 1945.

Oleh karena itu, tingkat daya guna sebuah desain kepemerintahan bergantung pada kualitas layanan yang diberikan oleh organisasi sektor publik.

Organisasi sektor publik sebagai badan yang identik dengan pemerintahan negara merupakan suatu lembaga yang berorientasi kepada kepentingan publik sehingga organisasi sektor publik bukan mementingkan laba sebagai target akhirnya (Bastian, 2019; Sujarweni : 20, 2016). Sebagai representasi Negara, organisasi sektor publik memiliki peran yang sangat penting terhadap penyelenggaraan pelayanan publik yang optimal sehingga selalu menjadi garda terdepan dalam pelayanan publik guna terciptanya kesejahteraan masyarakat (Sururi, 2019).

Reformasi akuntansi sektor publik dinilai menjadi salah satu prasayarat penting dalam keberhasilan pelaksanaan suatu reformasi karena dianggap menyangkut dengan reformasi bidang lainnya. Faktor penting yang menjadi kunci terjadinya reformasi di bidang keuangan daerah Indonesia yaitu mengamanatkan bahwa pentingnya pengelolaan keuangan yang akuntabilitas serta transparan (Good Governance). Perwujudan akan good governance membutuhkan hubungan antara pihak birokrasi, masyarakat, dan juga swasta berdasarkan prinsip-prinsip transparansi serta akuntabilitas (Santosa dkk., 2016).

Menurut Maryam (2016) dalam penelitiannya tentang mewujudkan good governance melalui pelayanan publik menyimpulkan bahwa pengelolaan pemerintahan yang baik (good governance) pada dasarnya menuntut agar memberikan pelayanan yang sesuai dalam memenuhi setiap kebutuhan masyarakat. Hal ini perlu diakukan demi memanifestasikan pelayanan publik yang unggul sesuai seperti yang diamanatkan pada pembukaan UU Dasar 1945 yaitu mewujudkan kesejahteraan masyarakat secara adil serta merata. Berbagai perubahan dalam akuntansi sektor publik Indonesia baik itu dalam penerapan teknik maupun regulasi yang dikeluarkan oleh pemerintah Indonesia, ditujukan agar tercapai pengelolaan keuangan negara yang baik. Segala perubahan tersebut mengarah pada tuntutan agar terbentuknya kelembagaan pemerintah yang akuntabel, transparan serta dapat menanggapi akan reformasi secara efektif.

Teknologi menjadi salah satu tanda adanya perubahan atau kemajuan zaman. Perkembangan teknologi ini menjadikan pekerjaan yang sebelumnya membutuhkan penyelesaian secara manual kemudian membutuhkan waktu yang pada umumnya lama menjadi semakin praktis serta cepat. Menurut Zubaidi dkk. (2019) dalam penelitiannya tentang pemanfaatan teknologi informasi terhadap kualitas laporan keuangan menyimpulkan bahwa pengimplementasian Teknologi Informasi dan Komunikasi (TIK) dibandingkan memakai metode interaktif tradisional dinilai mempunyai keunggulan tersendiri yang tentunya lebih menguntungkan sehingga menjadi tujuan utama penerapan TIK tersebut. Hal tersebut sejalan dalam mendukung jalannya organisasi sektor publik agar terus melakukan pengembangan dan perubahan dalam pelayanan sektor publik. Dalam pengelolaan birokrasi sektor lembaga-lembaga negara, pemanfaatan TIK ini dikenal dengan sebutan E-Government (Wahyuningsih \& Purnomo, 2020a).

E-Government adalah sistem informasi manajemen berbasis TIK yang dibentuk untuk demi kepentingan pelayanan publik yang kemudian digunakan sebagai instrumen interaktif informasi serta komunikasi antara instansi internal dalam pemerintahan maupun dengan pihak publik (masyarakat). Sistem ini berperan penting dalam meningkatkan akses dan efisiensi serta penyediaan informasi dan layanan pemerintahan (Crespo dkk., 2017).

Menurut Wahyuningsih dan Purnomo (2020) dalam penelitiannya mengenai penerapan e-government di Korea Selatan dan Indonesia menyimpulkan bahwa e-government merupakan sebuah upaya yang dilakukan oleh pemerintah berfungsi sebagai pelayanan kepada masyarakat. Hal ini juga termasuk dalam memberikan informasi berupa keterangan penjelas informasi tersebut yang berbasis elektronik terkait pengadaan anggaran serta perkembangan bagaimana proses penggunaan anggaran yang dilakukan oleh pemerintahan sebagai wujud dalam pelayanan publik yang transparan (Gunawan, 2016).

Penggunaan e-government sendiri mulai bergulir di bawah naungan hukum sejak munculnya INPRES No. 3 Tahun 2003 yang lahir dengan maksud agar menghilangkan sekat antara pihak birokrasi dan publik dengan membuka kesempatan dalam pengaksesan informasi bahkan pengizinan pengelolaan informasi yang berjumlah besar secara efektif dan efisien untuk memanifestasikan penyelenggaraan pemerintah yang akuntabilitas dan transparan (Muflihah \& Susanto, 2017; Musfikar, 2018; Sipahutar \& Sutaryo, 2017; Wahyuningsih \& Purnomo, 2020a). Hal ini membuktikan bahwa pemerintah telah memahami pengimplementasian TIK menjadi salah satu kunci penting dalam proses pelayanan publik yang berimplikasi terhadap kemajuan bangsa dan negara.

Corruption Perception Index (CPI) atau lebih dikenal dengan Indeks Persepsi Korupsi (IPK) yang dikeluarkan oleh lembaga Transparency International Indonesia menyebutkan bahwa pada tahun 2020 Indonesia berada di angka 37 pada skala 0-100 dengan 
rangking 102 dari 180 negara. Adapun skor 0 sangat korup dan skor 100 sangat bersih. Sebelumnya pada tahun 2019 Indonesia berada di angka 40 dengan rangking 85 dunia.

Adanya penurunan indeks persepsi korupsi tersebut menandakan bahwa e-government dinilai sebagai sebuah solusi terkait persoalan nasional tersebut. Oleh karena itu pemanfaatan TIK yang canggih perlu dioptimalkan dalam pelayanan sektor publik guna menjunjung tinggi adanya transparansi serta akuntabilitas. Sehingga lewat pengimplementasian egovernment, semua pihak birokrasi, pihak swasta, publik, maupun pihak terkait yang lain bisa menggunakan informasi dan layanan pemerintahan yang terbaik setiap saat (Wahyuningsih \& Purnomo, 2020a). Penerapan sistem tersebut akan semakin menyongsong perwujudan good governance di Indonesia.

Dalam rangka membantu perwujudan prinsip good governance dan menyediakan fasilitas pemerintahan dalam menghadapi terjadinya berbagai reformasi akuntansi daerah, Badan Pengawasan Keuangan dan Pembangunan (BPKP) melalui Deputi Pengawasan Bidang Penyelenggaraan Keuangan Daerah telah merancang sebuah program aplikasi penganggaran berbasis elektronik dan juga merupakan salah satu bagian dari program e-government yaitu berupa $e$ budgeting. E-Budgeting itu sendiri yaitu sebuah sistem informasi yang berfungsi sebagai penyusunan serta pengelolaan anggaran mulai dari tahap perencanaan penganggaran hingga pertanggungjawaban anggaran berbasis web serta terdapat program didalamnya guna membantu meningkatkan keterbukaan dan akuntabilits pemerintah dalam proses anggaran (Gunawan, 2016; Khoirunnisak dkk., 2017; Lathifah \& Toni Roby Candra Yudha, 2018; Setyawan \& Gamayuni, 2020).

Penyusunan anggaran secara elektronik atau $e$ budgeting sangat berperan penting dalam penyusunan anggaran di sektor publik yang dilakukan oleh departemen pemerintahan, sebagai bentuk wujud nyata pengelolaan keuangan daerah yang transparan kepada masyarakat (Gamayuni \& Hendrawaty, 2020; Tarigan dkk., 2017). Sistem ini dapat digunakan secara online serta mampu diakses dari mana saja, sehingga waktu yang dibutuhkan dalam proses penganggaran dapat dikurangi. Sistem ini sengaja diciptakan berbasis online sehingga bisa diakses oleh siapa saja pihak yang berwewang dan dilokasi manapun baik itu saat pembahasan dengan dewan maupun saat pengawasan. Masyarakat juga dapat mengaksesnya jika ingin mengetahui bagaimana kinerja pemerintah dan juga sirkulasi keuangan daerah. Sehingga, sistem tersebut berfungsi dengan sesungguhnya bagi masyarakat sebagai media dalam pengawasan baiik itu kinerja maupun proses dalam pembentukan anggaran sektor publik.
Kemudian, prosedur yang sifatnya saling mengawasi telah disusun dalam e-budgeting juga berfungsi sebagai alat dalam mengantisipasi terjadinya mark-up atau tindakan tidak bertanggungjawab mengenai pembentukan dan pengelolaan anggaran (Adila \& Dahtiah, 2020; Dini dkk., 2019).

Program ini dapat digunakan oleh pemerintah daerah maupun pemerintah pusat sehingga prinsip good governance dapat diterapkan dan berdampak kepada peningkatan kinerja keuangan sektor publik pada pemerintah daerah di Indonesia. Prinsip tata kelola keuangan yang baik akan mempengaruhi kinerja pemerintah yang menyajikan atau yang membuat laporan keuangan (Nasution \& Agustina, 2019). Maka dari itu, semakin berjalan dengan efektif implementasi ebudgeting maka diharapkan akan memperoleh manfaat lebih baik lagi. Sehingga dapat diwujudkan kualitas penyelenggaraan pemerintahan yang baik, bersih, dan bebas korupsi, kolusi, serta nepotisme sesuai dengan harapan masyarakat dan juga harapan bangsa Indonesia. Oleh karena itu, peneliti tertarik untuk melakukan penelitian mengenai faktor-faktor yang mempengaruhi penerapan e-budgeting dalam sektor publik dengan menggunakan tinjauan literatur sebagai instrumen penelitian.

\section{METODE}

Pendekatan literature review (tinjauan literatur) merupakan metode yang digunakan dalam penulisan penelitian ini. Berdasarkan definisi, literature review merupakan sebuah karya orisinil yang merangkum dan mensistesis penelitian sebelumnya tentang sebuah topik tertentu (Thorne dkk., 2019). Penelitian literature review berisi ulasan, rangkuman, serta pemikiran penulis dengan melakukan peninjauan berbagai dokumen baik internasional maupun nasional, seperti publikasi akademis, publikasi pemerintah, UU dan peraturan, jurnal, buku, berita media, dan bentuk catatan lain yang relevan dengan topik yang dibahas (Massaro dkk., 2016; O'Connor dkk., 2017; Yuhertiana, 2015). Tujuan akhir dari metode tinjauan literatur yaitu agar memperoleh deskripsi detail yang berhubungan dengan sesuatu yang orang atau peneliti lain sudah kerjakan sebelumnya (Alahi \& Mukhopadhyay, 2019; Suryanarayana \& Mistry, 2016).

Proses dalam melakukan sebuah tinjauan literatur, pada umumnya dibagi menjadi 3 tahap utama yaitu planning, conducting dan reporting (Santis dkk., 2018; Zhu dkk., 2018). Maka dari itu, metodologi penelitian yang diterapkan dalam studi ini didasarkan pada langkah-langkah yang terstruktur dan tersusun.

Tahap pertama yang harus dilakukan yaitu planning (perencanaan). Dalam setiap perencanaan penelitian yang akan dibangun pasti terdapat tujuan atau 
hasil akhir yang ingin dicapai. Pertama studi ini bertujuan untuk menggambarkan dan mendokumentasikan tentang bagaimana fenomena reformasi akuntansi sektor publik di Indonesia membangun perwujudan transparansi dalam pelayanan sektor publik melalui pengelolaan anggaran berbasis elektronik. Kedua, tujuan utama dari studi ini yaitu mendeskripsikan bagaimana faktor-faktor yang mempengaruhi dalam pengimplementasian dari $e$ budgeting itu sendiri.

Tahap yang kedua yaitu conducting (melakukan review). Peneliti perlu ketelitian dalam mencermati apakah relevan atau tidaknya setiap literatur yang digunakan, lalu perlu adanya ketentuan dalam melakukan seleksi sumber data, bagaimana proses dalam ekstrasi dari data yang didapat, bagaimana cara mengkaji dan melakukan sintasis sumber data agar memperoleh hasil review yang memuaskan. Jenis data dalam penelitian ini yaitu jenis data sekunder, karena semua data bersumber dari internet sehingga tidak dikumpulkan secara langsung.

Pencarian literatur daIam peneIitian ini dimuIai dengan memiIih artikeI dari database akademik yang bereputasi tinggi sampai rendah antaralain seperti Web of Science Group , Scimago, ProQuest, EBSCO, Emerald Insight, dan Google Scholar dengan menggunakan kata kunci "Reformasi akuntansi" atau "Accounting Reform”, “E-Government" atau "Electronic Government", dan "E-Budgeting" atau "Electronic Budgeting". Selain itu, penambahan keyword "Akuntansi Sektor Publik" atau "Public Sector Accounting” di tiap-tiap keyword dalam pencarian literatur juga dilakukan jika hasil dari pencarian memunculkan jumlah yang banuak agar relevan dengan topik pembahasan.

Tabel 1. Daftar Kata Kunci Pencarian

\begin{tabular}{|c|c|c|c|c|}
\hline \multirow[b]{2}{*}{$\begin{array}{l}\mathrm{N} \\
\mathrm{O}\end{array}$} & \multirow[b]{2}{*}{$\begin{array}{c}\text { Database } \\
\text { Akademik }\end{array}$} & \multicolumn{3}{|c|}{ Kata Kunci } \\
\hline & & $\begin{array}{l}\text { Reformasi } \\
\text { Akuntansi }\end{array}$ & $\begin{array}{c}\text { E- } \\
\text { Gover } \\
\text { nment }\end{array}$ & $\begin{array}{c}\text { E- } \\
\text { Budgeting }\end{array}$ \\
\hline 1 & $\begin{array}{l}\text { Web of } \\
\text { Science } \\
\text { Group }\end{array}$ & 0 & 1 & () \\
\hline 2 & $\begin{array}{l}\text { Scimago } \\
\text { Journal \& } \\
\text { Country }\end{array}$ & () & 51 & 2 \\
\hline 3 & Pro Quest & 81 & 34 & 2 \\
\hline 4 & EBSCO & 0 & 0 & () \\
\hline 5 & $\begin{array}{l}\text { Emerald } \\
\text { Insight }\end{array}$ & 226 & 67 & 2 \\
\hline 6 & $\begin{array}{l}\text { Google } \\
\text { Scholar }\end{array}$ & 343 & 424 & 78 \\
\hline
\end{tabular}

Pencarian literatur ini juga melakukan pengulangan dengan menghapuskan tanda hubung.
Tetapi penghapusan tanda hubung justru memunculkan artikel dengan topik fokus lain, tidak menghasilkan makalah tambahan baru yang relevan sesuai dengan topik pembahasan. HasiI peneIusuran tersebut menemukan 1.331 artikeI peneIitian dari jumlah total dari masing-masing database yang membahas tentang implementasi e-budgeting dalam pengelolaan keuangan di sektor publik.

Pada tinjauan Iiteratur ini penuIis menyeIeksi artikeI yang ditemukan pada database akademik tersebut menggunakan beberapa kriteria, diantaranya yaitu: (1) ArtikeI peneIitian asIi (bukan merupakan review peneIitian), (2) Diterbitkan oIeh jurnaI/prosiding akuntansi, (3) peneIitian diIakukan daIam rentang waktu 5 tahun (2016-2020), (4) artikeI peneIitian diterbitkan fuII-text daIam Bahasa Indonesia maupun Bahasa Inggris yang merupakan bahasa yang digunakan oleh penulis (5) pemilihan literatur dipilah sehingga tidak ada duplikasi artikel yang akan direview, dan (6) mengkaji tentang implementasi dari e-budgeting dalam pengelolaan keuangan di sektor publik.

Dari kriteria tersebut menghasiIkan 34 artikeI yang digunakan sebagai sumber literatur daIam studi ini sehingga artikeI ini diharapkan dapat memberikan dasar teoritis untuk peneIitian masa depan tentang reformasi akuntansi sektor pubIik dalam pengelolaan keuangan dan dapat membantu pemerintah daerah daIam merumuskan tentang bagaimana menerapkan perubahan dan perbaikan daIam pelayanan sekor publik.

Tahapan ketiga atau yang terakhir yaitu melakukan reporting (pelaporan). Pada tahap ini penulis menuangkan hasil review literatur yang telah dianalisis menggunakan sistematika penulisan yang akan dituliskan dalam sebuah paper jurnal ilmiah. Penulis melakukannya dengan penuh ketelitian dan pemahaman yang mendalam terkait setiap informasi yang ada agar studi ini bisa memberikan manfaat secara maksimal untuk pembaca.

\section{HASIL DAN PEMBAHASAN}

Implementasi kerap dipandang hanya sebatas pelaksanaaan dari apa yang telah ditetapkan oleh pihak pengambil keputusan. Namun pada praktiknya, tahapan implementasi berperan sangat penting karena jika suatu kebijakan tidak dapat dilaksanakan dengan sesungguhsungguhnya maka tidak akan ada manfaatnya. Oleh karena itu, dapat disimpulkan bahwa implementasi adalah suatu kebijakan yang diterapkan secara optimal sehingga bisa memperoleh tujuan utama yang diinginkan oleh kebijakan tersebut. Sehingga, ada beberapa faktor yang mempengaruhi penerapan suatu program atau kebijakan dalam suatu organisasi sektor publik. 


\section{Struktur Birokrasi}

Adanya mekanisme atau prosedur kerja di dalam sebuah pengelolaan kebijakan. itulah yang dinamakan dengan Struktur Birokrasi (Juliar \& Dahtiah, 2020). Sebuah struktur birokrasi memiliki fungsi penting terkait sebuah kebijakan yaitu dengan menyusun Standard Operating Procedures (SOP).

Berdasarkan penelitian Adila \& Dahtiah (2020) sitem e-budgeting dalam penerapannya harus direncanakan secara matang bagi tiap-tiap manajemen pemerintahan. Tentunya hal ini sebagai penunjang perwujudan implementasi e-budgeting. Selain itu, otorisasi atau dukungan dari berbagai pimpinan instansi sangar dibutuhkan demi memudahkan implementasi dan penggunaan sistem e-budgeting. Berdasarkan struktur birokrasi pengaplikasian kebijakan e-budgeting sesuai dengan SOP yang berpedoman pada Permendagri No. 13 tahun 2006 yang membahas soal pengelolaan Keuangan Daerah yang kemudian diganti menjadi Permendagri No. 59 tahun 2007, Permendagri No. 33 tahun 2019, Peraturan No. 58 tahun 2005 dan Pedoman Tahunan APBD.

Masing-masing daerah memiliki struktur birokrasi yang berbeda dalam penerapan e-budgeting sebagai wujud dalam pengelolaan anggaran. Seperti pada Pemerintah Kota Surakarta yang dinaungi oleh tiga instansi inti yaitu BPPKAD, Bappeda, dan Diskominfo SP Kota Surakarta (Julianty, 2020). Lain halnya dengan struktur birokrasi dari Pemerintah Kota Bandung dalam pengelolaan e-budgeting. Berdasarkan studi Juliar \& Dahtiah (2020) dan Sagita \& Mariana (2017), ebudgeting dikelola oleh SKPD selaku user, TAPD yang dikepalai oleh Sekda, Bappelitbang, BPKA, dan Diskominfo.

Begitupula dengan Kota Surabaya sebagai pelopor dalam penggunaan sistem e-budgeting di Indonesia khususnya Provinsi Jawa Timur. Kesuksesan penerapan e-budgeting oleh Kota Surabaya menjadikan kota yang telah menerapan sistem e-budgeting setiap SKPD dan kelurahan, kecamatan dan dinas (Gunawan, 2016). Sama halnya dengan kesuksesan penerapan $e$ budgeting di Kota Jakarta yang menjadi salah satu kota panutan di Indonesia dalam pengimplementasian sistem e-budgeting. Hal itu sudah dilaksanakan oleh tiap SKPD sesuai dengan SOP dari Kepala Tim Anggaran dan Sekda (Oktaviani dkk., 2019). Mengenai koordinasi dan kerjasama yang dilakukan antar pihak-pihak terkait yaitu dengan melakukan rapat rutin ketika perencanaan dan penganggaran.

\section{Sumber Daya}

Dalam pengimplementasi sebuah kebijakan harus ditunjang oleh sumber daya fisik maupun non fisik. Keberhasilan dari penerapan kebijakan yang dilakukan oleh implementator sangat didukung oleh adanya sumber daya fisik. Untuk memperlancar dalam proses pengelolaan sebuah kebijakan, sumber daya fisik sangat diperlukan dalam hal tersebut. Jika tidak adanya sumber daya fisik yang layak, maka penerapan sebuah kebijakan tidak bisa berjalan efektif.

Disatu sisi, sumber daya manusia adalah salah satu faktor penunjang dalam keberhasilan pengimplementasian e-budgeting. Karena hal itu maka diperlukan adanya sumber daya yang paham dan kompeten untuk menjalankan suatu program. Sumber daya manusia yang dimiliki tidak cukup bila hanya sekedar tau dan tidak terlalu paham mengenai apa yang menjadi tugasnya, idealnya sumber daya manusia yang dimiliki haruslah kompeten dalam hal e-budgeting, seperti dalam hal pengelolaan keuangan, sistem informasi, dan lainnya (Gamayuni, 2020). Dengan demikan, hasil ini sesuai dengan hasil studi yang dilakukan oleh Saputra dkk. (2019) yang menyatakan efektivitas implementasi kebijakan e-budgeting dipengaruhi oleh kemampuan sumber daya manusianya.

Menurut Juliar \& Dahtiah (2020) dalam penelitiannya tentang implementasi e-budgeting Pemerintah Kota Bandung, menyimpulkan bahwa dalam bidang sumber daya manusianya sudah mumpuni sehingga hal ini tentunya telah menunjang keberhasilan setiap tahunnya dalam menyusun APBD. Namun, tetep adanya penyesuaian yang harus dilakukan karena adanya Perubahan pola pikir yang baru, sudah mulai terbiasa dan dipahami oleh SKPD. Waktu sosialisai dan pelatihan yang sangat singkat, dan waktu penetapan RKPD 2017 dan APBD 2017 tidak sesuai dengan jadwal. Serta penyesuaian sistem yang banyak tidak sesuai dengan muatan lokal sehingga membutuhkan penyesuaian.

Dalam penelitian Sagita \& Mariana (2017) justru memunculkan hasil lain dalam pemberdayaan sumber daya manusia pada penerapan e-budgeting di Kota Bandung. Beberapa aparatur dan sebagian besar pemimpin masih memiliki keyakinan terhadap paradigma tradisional dan budaya birokrasi. Bahwa penganggaran dalam sektor publik harusnya dijadikan sebagai preferensi pelaku anggaran di antara birokrasi daerah yang menganggap penggunaan anggaran sebagai peluang untuk menyerap anggaran sebesar-besarnya, dengan menikmati fasilitas yang diperoleh dari negara, sehingga menguntungkan kepentingan ekonomi swasta dan sekelompok orang yang berpengaruh. Hal ini tentunya justru menjadi penghambat dalam pengimplementasian e-budgeting. Sehingga tujuan utama penerapan e-budgeting itu sendiri tidak akan tercapai.

Berdasarkan pemaparan diatas, dapat disimpulkan bahwa sumber daya dalam penerapan $e$ budgeting salah satunya sumber daya manusia yang 
sudah mumpuni sangat mempengaruhi pengimplementasian e-budgeting dalam sektor publik.

Kemudian, tidak hanya sumber daya manusia yang mendukung implementasi e-budgeting melainkan terdapat sumber daya finansial sebagai salah satu penentu keberhasilan. Misalnya Pemerintah Kota Surkarta menganggarkan nilai yang besar untuk pelaksanaan e-budgeting yang sedang berjalan saat ini (Julianty, 2020). Selain sumber daya tersebut, juga terdapat beberapa sumber daya yang dibutuhkan dalam penerapan e-budgeting, antara lain mesin atau server yang dikembangkan oleh Pemerintah dan metode norma atau peraturan yang dipakai

Kemudian, dalam studi Juliar \& Dahtiah (2020) e-budgeting Kota Bandung sendiri sudah mempunyai Peraturan WaliKota dalam standar kebijakan dalam pengelolaan sistem e-budgeting. untuk melaksanakan kebijakan e-budgeting, pihak-pihak yang mengoperasikan dan menggunakan e-budgeting yaitu SKPD yang menginput anggaran dan selanjutnya pihak TAPD yang merekap anggaran yang telah diinput oleh SKPD sebelumnya.

Selain berbagai sumber daya pendukung yang telah dijabarkan, terdapat pula hambatan sumber daya yang sering dialami dalam penerapan e-budgeting yaitu koneksi internet, hardware, dan software yang kurang mumpuni. Hal ini sejalan dengan penelitian Adila \& Dahtiah (2020) yang menyimpulkan bahwa kondisi fasilitas sangat menunjang penerapan e-budgeting. Penelitian Gamayuni (2020) juga menyimpulkan bahwa penerapan e-budgeting di provinsi lampung terhambat dikarenakan hardware yang kurang mumpuni.

Namun, hal itu tidak selalu menjadi hambatan bagi tiap Kota yang menerapkan e-budgeting. Misalnya, keberhasilan implementasi sistem e-budgeting di Surabaya yang dilatarbelakangi oleh adanya sumber daya manusia yang berkompeten disertai dengan dukungan hardware sehingga tentunya hal itu akan mendukung dan membantu kelancaran implementasi dari sistem $e$ budgeting (Gunawan, 2016).

\section{Komunikasi}

Keberhasilan dari implementasi suatu kebijakan publik adalah dengan memahami langkah atau proses yang akan dilakukan demi pencapaian tujuan. Penyampaian tujuan serta sasaran suatu kebijakan, seharusnya diberikan pemahaman secara jelas kepada kelompok sasaran, apabila tidak maka kemungkinan akan terjadinya suatu penolakan. Oleh sebab itu, komunikasi sangatlah dibutuhkan untuk para pembuat keputusan dan para implementator semakin konsisten dalam melaksanakan setiap kebijakan yang akan diterapkan dalam masyarakat.
Dalam penelitian Juliar \& Dahtiah (2020) menjelaskan tujuan utama yang hendak dicapai dengan di terapkannya e-budgeting di Pemerintah Kota Bandung yaitu mengarah pada performance best budgeting dengan menjaga koherensi antara penyusunan serta penganggaran. Memastikan bahwa rincian belanja sesuai dengan RPJMD, Renstra Perangkat Darah dan Renja.

Penyaluran informasi mengenai e-bugdeting di Pemerintah Kota Bandung, dilakukan dengan sosialisasi-sosialisasi yang dilakukan pada tahun 2016 oleh konsultan. Pada saat sosialisasi pertama kali para pelaku SKPD kesulitan untuk memahaminya, karena tidak adanya kasus secara nyata. Dipermudah dengan pendampingan secara langsung ketika penyusunan perencanaan dan anggaran.

Kemudian, berdasarkan penelitian Julianty (2020) pelaksanaan e-budgeting pada pemerintah Kota Surakarta ditujukan untuk mewujudkan salah satu program dari Walikota Surakarta yaitu Berperilaku jujur baik sikap maupun wewenang, memberantas PungLi, dan bekerja berdasarkan aturan atau undang-undang yang berlaku. Selain itu juga merupakan amanat dari UU No. 14 Tahun 2008 yang membahas mengenai Keterbukaan Informasi Publik. Oleh karena itu, program Walikota serta amanat yang tertuang dalam Undang-Undang menjadikan pelaksana kebijakan yang transparan serta akuntabel kepada masyarakat. Tentunya akan mendukung terwujudnya komunikasi yang baik diantara intern pelaksana kebijakan maupun diantara pelaksana kebijakan dengan masyarakat. Selain itu juga masyarakat dapat dengan mudah mengakses website pemerintah untuk mengetahui perkembangan terbaru dari Kota Surakarta.

Penelitian Adila \& Dahtiah (2020) juga menyimpulkan bahwa komunikasi juga penting dalam pihak internal pemerintah. Dukungan dan komunikasi dari masing-masing kepala instansi kepada bawahannya dapat menunjang dalam pengimplementasi serta pengelolaan sistem e-budgeting.

Berdasarkan hal tersebut, dapat disimpulkan bahwa komunikasi dalam kebijakan e-budgeting tersebut pada saat sosialisasi sulit untuk dipahami oleh para pengguna, karena tidak adanya kasus nyata. Seiring berjalannya waktu dengan dilakukannya sosialisasi berkali-kali dan bimbingan teknologi maka para pengguna e-budgeting sudah terbiasa. Sehingga, komunikasi berperan penting dalam pengembangan sistem e-budgeting.

\section{Disposisi}

Disposisi merupakan sikap dan komitmen dalam pelaksanaan suatu kebijakan atau program yang harus dijalankan karena setiap kebijakan yang telah 
disepakati membutuhkan implementator yang memiliki keinginan yang kuat dan komitmen yang tinggi untuk mewujudkan tujuan kebijakan seperti yang diharapkan. Jika sebuah pelaksanan kebijakan ingin efektif maka para pelaksana kebijakan tersebut harus mengetahui apa saja yang harus dilakukan tetapi juga harus memiliki kemampuan yang berkompeten untuk melaksanakan hal tersebut sehingga dalam prakteknya tidak terjadi bias. Komitmen dalam menjalankan kebijakan ebudgeting disebutkan bahwa para pelaksana melaksanakannnya dengan komitmen yang cukup baik.

Seperti halnya dalam penggunaan e-budgeting pada Kota Bandung yang konsisten dari sisi perencanaan dan penganggaran tetapi e-budgeting sendiri telah mengalami beberapa perubahan dari versi 1.0 hingga versi 4.0 karena kebutuhan (Juliar \& Dahtiah, 2020; Sagita \& Mariana, 2017).

Selain itu, dalam penelitian Julianty (2020) menyimpulkan bahwa respon implementor Kota Surakarta dalam kebijakan e-budgeting ini cukup baik. Hal ini juga didukung karena dengan adanya pemahaman yang ditanamkan pada implementor kebijakan bahwa segala apa yang menjadi tugasnya juga harus dipertanggungjawabkan kepada masyarakat. Sehingga menimbulkan pemerintahan yang akuntabel.

Kemudian, setelah memahami faktor-faktor yang mempengaruhi implementasi dari sistem ebudgeting; maka perlu diketahui bagaimana penerapan e-budgeting di Indonesia selama ini. Studi kali ini akan membahas beberapa kota besar yang ada di Indonesia.

\section{Implementasi E-Budgeting di Kota Surabaya}

Provinsi Jawa Timur adalah pionir terkait penerapan sistem e-budgeting yaitu Ibu Kota dari provinsi tersebut, Kota Surabaya. Keberhasilan pengimplementasian e-budgeting yang diterapkan oleh kota Surabaya menjadi bukti nyata fungsi penting dari sitem yang menghasilkan transparansi dalam pelayanan sektor publik tersebut. Selain itu, pemerintah Kota Surabaya juga mendapatkan berbagai penghargaan terkait penerapan e-budgeting guna menunjang pelayanan birokrasi.

Surabaya sendiri dinilai sebagai kota yang memiliki inovasi, efisiensi, serta keunggulan dalam pengelolaan manajemen proyek di pusat data. Fasilitas teknologi informasi ini dapat dinikmati oleh seluruh masyarakat Surabaya secara gratis agar mewujudkan pelayanan dan data informasi secara transparan, akuntabel dan mengurangi batas birokrasi (Gunawan, 2016).

Berdasarkan proses implementasi sistem ebudgeting pada kota Surabaya sudah berhasil sesuai dengan SOP yang dirumuskan oleh Walikota serta Sekretaris Daerah bersama Tim Anggaran. Dimulai dari proses perencanaan, pelaksanaan dan evaluasi. Namun, penggunaan e-budgeting ini belum dapat diakses secara terbuka oleh masyarakat. Walaupun demikian, masyarakat tetap bisa mengawasi pengelolaan anggaran melalui website-website dari BAPPEDA, PPID, DPRD, BPKAD atau bahkan situs pemerintahan transparansi pengelolaan anggaran lainnya. Diharapkan dengan adanya kontrol yang dilakukan oleh masyarakat dapat memberikan aksesibilitas dan keterbukaan informasi dalam proses anggaran. Dengan demikian tercipta peran sesungguhnya masyarakat agar ikut serta dalam penyusunan rencana kegiatan Pemerintahan Kota Surabaya.

\section{Implementasi $\boldsymbol{E}$-Budgeting di Kota Jakarta}

Proses implementasi sistem e-budgeting pada kota Surabaya sudah berhasil sesuai dengan SOP yang dirumuskan oleh Gubernur dan Sekretaris Daerah. Hal itu dibuktikan dengan tidak hanya mendapatkan banyak penghargaan dalam pengimplementasian e-budgeting, tetapi kini telah menjadi kota teladan bagi kota lain di Indonesia dalam penerapan sistem e-budgetingnya (Oktaviani dkk., 2019).

Fungsi anggaran yang berperan besar dalam pelaksanaan program serta kebijakan pemerintah akan sangat beresiko apabila didalam pengelolaanya terjadi penyimpangan (korupsi). Selain itu, pelaksanaan APBD melalui e-budgeting dinilai telah memberikan efek positif yaitu menjadikan sifat APBD itu sendiri lebih terbuka baik dalam proses perencanaan maupun penganggaran.

Meskipun sama halnya dengan pemerintahan kota Surabaya yaitu dalam proses penganggaran masyarakat tidak dapat dilibatkan secara langsung, tetapi masyarakat tetap dapat mengawal atau mengawasi proses penganggaran yang dilakukan oleh pihak birokrasi. Dengan adanya website BAPPEDA, PPID, DPRD, BPKAD atau website transparansi pengelolaan anggaranl lainnya. Dengan cara ini, masyarakat akan dengan mudah menemukan dokumen rancangan dan anggaran, serta juga dapat mengawasi sejauh mana proses tersebut berjalan. Salah satu indikator untuk mengukur bagaimana transparansi pelayanan publik yaitu mudah atau tidaknya bagi masyarakat dalam memperoleh informasi tentang segala aspek terkait penyelenggaraan pelayanan publik. Diharapkan pula masyarakat semakin memperkuat kontrol dan pengawasan terhadap sistem pengelolaan anggaran pemerintah kota.

\section{Implementasi E-Budgeting di Kota Bandung}

E-Budgeting Pemerintah Kota Bandung

bernama Sistem Informasi Perencanaan dan Penganggaran (SIRA). Sama halnya dengan pemerintah 
kota Surabaya dan Jakarta, pemerintah Kota Bandung telah menggunakan e-budgeting dalam penyusunan APBD, tetapi dalam sistem tersebut belum bisa diakses secara terbuka oleh masyarakat.

Implementasi Kebijakan e-budgeting dalam Pemerintah Kota Bandung sudah sesuai dengan SOP yang berlaku, dengan sumber daya manusia yang sudah terbiasa dan mumpuni serta sarana dan prasarana yang terus dikembangkan, komunikasi dengan cara sosialisasi yang dilakukan berkali-kali dan bimbingan teknologi, dan penerapan kebijakan e-budgeting dapat dipahami oleh seluruh pegawai sebagai pelaksana kebijakan (Juliar \& Dahtiah, 2020).

Dilihat dari keberhasilan kebijakan penerapan e-budgeting dan sistem pengendalian manajemen, dapat dibuktikan dengan terwujudnya transparansi yang dilakukan sudah sesuai dengan Undang-Undang No. 14 tahun 2008, akuntabilitas dalam penyusunan APBD lebih bisa dipertanggungjawabkan dan lebih terukur, serta efektifnya penetapan APBD yang dilakukan tepat waktu dan berhasil melakukan efisiensi pada anggaran belanja (Dini dkk., 2019).

Selain dipandang dari keberhasilannya, namun tujuan utama dari penerapan e-budgeting belum dapat diterima atau dipahami oleh sebagian besar pimpinan dan aparatur di wilayah Bandung. Hal ini disebabkan masih kuatnya paradigma lama dan budaya birokrasi. Paradigma lama dan budaya birokrasi menunjukkan preferensi pelaku anggaran di antara birokrasi daerah yang menganggap penggunaan anggaran sebagai peluang untuk menyerap anggaran sebesar-besarnya, dengan menikmati fasilitas yang diperoleh dari negara, sehingga menguntungkan kepentingan ekonomi swasta dan sekelompok orang yang berpengaruh (Sagita \& Mariana, 2017).

Perlahan-lahan mulai adanya sosialisasi edukasi tentang pentingnya penggunaan e-budgeting sehingga pola pikir aparatur tidak lagi dengan paradigma yang lama. Sehingga bisa menyadarkan bahwa dalam proses e-budgeting sangat diperlukan untuk menyadarkan para pimpinan perangkat daerah bahwa anggaran kegiatan merupakan amanah dari masyarakat yang harus dikelola dengan baik dan bertanggung jawab.

Revolusi anggaran di Kota Bandung melalui ebudgeting dilaksanakan agar pengelolaan anggaran pemerintah daerah lebih diarahkan pada pencapaian tujuan pembangunan dan pemenuhan kebutuhan masyarakat akan barang atau jasa yang disediakan oleh pemerintah secara optimal. Melalui e-budgeting ini, Pemerintah Kota Bandung melakukan perubahan pada sistem penganggaran yang berupaya menekan kebocoran dan pemborosan anggaran yang diajukan oleh masing-masing perangkat daerah.
Agar sistem e-budgeting dapat terlaksana dengan baik maka diperlukan peningkatan kapasitas sumber daya aparatur melalui peningkatan pemahaman dan kemampuan dalam perencanaan dan penganggaran sehingga dapat menganalisis kebutuhan anggaran untuk membiayai masukan dan proses kegiatan dan keluarannya, sesuai dengan sasaran dan tujuan yang ingin dicapai.

\section{Implementasi E-Budgeting di Kota Batu}

Penerapan e-budgeting di Kota Batu sangat berdampak positif terhadap pengelolaan anggaran pemerintahan. Sebelum dilaksanakan e-budgeting banyak terjadi kesalahan entry manual anggaran (kesalahan entry data karena kurang tepat dan tidak sinkron dengan kode rekening) dan setelah dilaksanakan e-budgeting membuktikan kesuksesan $e$ budgeting.

Dalam penelitian Andhayani (2020) membuktikan bahwa pelaksanaan sistem informasi pemerintah daerah dalam hal e-budgeting dari awal rancangan, pelaksanaan telah mengalami beberapa perubahan dan kemajuan untuk perbaikan walaupun masih banyak terdapat kekurangan dalam hal tekhnologi, penerapan dalam system. Namun sangat dibutuhkan beberapa hal pendukung implementasi dari e-budgeting itu sendiri, seperti sumber daya manusia yang berkompeten sehingga mampu menangani $e$ budgeting dan dukungan serta koordinasi dari pejabat yang berwewenang serta koordinasi dari semua pihak.

Terdapat beberapa kendala utama dalam penerapan e-budgeting pada Kota Batu yaitu system yang belum terkoordinasi atau terintegrasi dengan system lainnya sehingga meyebabkan waktu untuk entry data sangat terbatas sehingga khawatir akan ketepatan angka dan kode rekening yang dimasukkan, ketepatan waktu entry data, adanya data yang tidak sama antara di system e-budgeting, ajuan hardcopy ataupun softcopy.

\section{Implementasi E-Budgeting di Kota Surakarta}

Dari implementasi e-budgeting pada Pemerintah Kota Surakarta ditemukan perbedaan yang cukup signifikan antara sebelum dan sesudah implementasi e-budgeting. Perbedaan pertama, adanya perbedaan sistem. Dimana saat ini dengan adanya globalisasi mengharuskan pemerintah untuk menerapkan teknologi informasi dalam hal pengelolaan keuangan daerah. Sedangkan sebelum implementasi $e$ budgeting, pemerintah hanya menggunakan sistem konvensional yang dimana proses perencanaan, penganggaran hingga pelaporan masih dilaksanakan secara manual.

Perbedaan kedua, saat ini dengan adanya $e$ budgeting masyarakat dapat lebih percaya kepada 
pemerintah dan tingkat kepercayaan dari masyarakat kepada pemerintah akan semakin tinggi. Selain itu pemerintah juga lebih bertanggung jawab terhadap perannya sebagai pelayan masyarakat.

Perbedaan ketiga, proses alur penyusunan anggaran. Dalam pelaksanaan penyusunan anggaran secara manual pemerintah membutuhkan waktu yang lama dan biaya yang mahal serta alur yang sangat panjang sehingga dalam pelaksanaannya tidak efektif dan efisien. Sedangkan dengan adanya pengelolaan keuangan daerah secara elektronik dapat lebih mempersingkat waktu penyusunan dan biaya yang tidak mahal karena terintegrasi satu sama lain mulai dari perencanaan, penganggaran hingga pelaporan.

Implementasi e-budgeting pada Pemerintah Kota Surakarta diterapkan melalui Simda terintegritas yang dikelola oleh BPPKAD, Bappeda, serta Diskominfo SP Kota Surakarta. Komunikasi yang dibangun antar organisasi perangkat daerah dan antara pemerintah dengan masyarakat dapat dilihat dari adanya kebijakan dan program-program kegiatan yang disampaikan langsung kepada masyarakat. Setiap organisasi perangkat daerah memiliki Sumber Daya Menusia yang bertugas untuk implementasi e-budgeting, namun masih belum ideal karena struktur SDM yang tidak dibentuk khusus. Keseriusan pemerintah Kota Surakarta dalam penerapan e-budgeting dapat dilihat dari pada pelaksanaan e-budgeting pada Pemerintah Kota Surakarta mengenai dana yang digunakan untuk sarana pendukung dari Diskominfo SP dapat di lihat dari DPA PD Tahun anggaran 2019-2020 yang memiliki nilai yang cukup besar.

Selain itu penerapan e-budgeting pada Kota Surakarta dijadikan sebagai perwujudan dari visi dan misi Kota Surakarta itu sendiri yaitu mewujudkan masyarakat yang tertib, aman, damai, berkeadilan, berkarakter dan berdaya saing melalui pembangunan darah yang akuntabel dan tata kelola pemerintahan yang efektif, bersih, responsif dan melayani. Tentunya ini searah dengan tujuan utama dari penerapan e-budgeting yaitu perwujudan Pemerintahan yang akuntabel dan transparansi demi terciptanya good governance dalam sektor publik.

Setelah penjelasan diatas, maka perlu dipahami bagaimana implikasi yang dihasilkan dari penerapan $e$ budgeting di Indonesia. Maka peneliti tertarik untuk membahas bagaimana perwujudan transparansi dalam pelayanan sektor publik sebagai tujuan utama dari penerapan e-budgeting itu sendiri.

\section{Perwujudan Transparansi sebagai Implikasi dari Penerapan E-Budgeting}

E-Budgeting menjamin konsistensi dan akuntabilitas antara perencanaan program dan kegiatan terhadap anggarannya. Partisipasi dan transparansi proses anggaran melalui e-budgeting memberikan informasi keuangan yang lebih relevan dan dapat diandalkan sebagai dasar penyusunan laporan keuangan pemerintah daerah yang berkualitas (Setyawan \& Gamayuni, 2020).

Secara filosofis, penerapan e-budgeting sangat prospektif dalam mewujudkan efisiensi dan efektivitas anggaran daerah. Hanya saja implementasi e-budgeting sangat bergantung pada kemampuan aparatur dalam menyusun rencana anggaran kegiatan dan budaya aparatur pemerintah dalam pengelolaan anggaran. Keberlangsungan implementasi e-budgeting ke depan juga sangat bergantung pada kebijakan pimpinan. Keberlangsungan e-budgeting bergantung pada kemauan politik pimpinan baru Bandung dan politik (Sagita \& Mariana, 2017).

Walaupun tujuan utama dari penerapan ebudgeting adalah wujud realisasi good governance yang didasarkan pada prinsip transparansi dan akuntabilitas publik serta perwujudan partisipasi masyarakat, namun di beberapa kota dalam proses penganggaran masyarakat tidak dapat ikut terlibat secara langsung. Tetapi masyarakat tetap dapat mengawasi jalannya proses penganggaran melalui situs pemerintahan lainnya. Sehingga, hak-hak masyarakat sebagai warga negara dalam pelayanan sektor publik tetap dapat tercapai (Oktaviani dkk., 2019). Penganggaran yang telah tersistem melalui e-budgeting dapat meningkatkan tingkat partisipasi masyarakat. Hal ini dikarenakan agar meminimalisir persoalaan terkait kepercayaan masyarakat terhadap pemerintah dalam pengawasan dan pengendalian anggaran sektor publik, pemerintah telah mengadopsi bentuk akuntabilitas serta transparansi informasi melalui sistem e-budgeting itu sendiri.

Dengan tersedianya informasi yang akurat dan memadai terkait penganggaran daerah, akan membangun serta menciptakan rasa saling percaya antara publik dengan pihak birokrasi. Peran transparansi sangat penting demi menambah tingkat keberhasilan dalam keputusan pengelolaan anggaran daerah. Hal ini dikarenakan berbagai informasi yang sebelumnya hanya dapat diakses oleh pihak birokrasi, demi perwujudan transparansi pelayanan sektor publik pemerintah dapat memberikan kesempatan kepada masyarakat dalam berpartisipasi terhadap pengambilan keputusan kebijakan anggaran misalnya dengan rapat yang dilakukan oleh perwakilan atau kepala desa setempat yang dilaksanakan berdasarkan asas musyawarah. Maka dari itu, dalam lingkup pengelolaan anggaran daerah dengan sendirinya akan meminimalisir peluang tindak pidana korupsi, kolusi maupun nepotisme.

Melalui sistem e-budgeting, para pejabat dan aparatur tidak dapat lagi menikmati fasilitas keuangan 
negara dan memboroskan anggaran dengan melakukan kegiatan yang dapat menguntungkan kepentingan ekonomi swasta. Melalui sistem e-budgeting, pejabat dan politisi daerah tidak bisa lagi mencuri keuangan negara untuk memulihkan modal politik yang habis terpakai pada masa pemilu. Melalui e-budgeting, seluruh usulan anggaran ditujukan untuk mencapai kegiatan-kegiatan yang sangat berkaitan dengan pemenuhan pelayanan publik dan pembangunan.

\section{PENUTUP}

\section{Simpulan}

Pelaksanaan perencanaan dan pengelolaan anggaran daerah dengan e-budgeting diharapkan dapat mengembangkan kualitas akuntabilitas kinerja instansi pemerintah yang lebih baik dan mampu menjunjung tinggi transparansi dalam pelayanan sektor publik. Beberapa faktor yang perlu diperhatikan dalam mengimplementasikan e-budgeting antara lain struktur birokrasi, sumber daya, komunikasi, dan dispoisi dalam organisasi sektor publik. Oleh sebab itu, dalam rangka pertanggungjawaban publik selain dalam penyusunan pelaporan keuangan pemerintah daerah diharapkan bahkan diwajibkan dapat melakukan optimalisasi anggaran yang dilakukan secara efisien dan efektif untuk meningkatkan kesejahteraan masyarakat.

Proses anggaran yang telah disepakati antara pemerintah daerah merupakan amanat rakyat. Ini adalah tantangan untuk menunjukkan bahwa sebagai pihak yang bertanggungjawab akan kepentingan rakyat pemerintah daerah harus memposisikan dirinya pada posisi yang tepat. Oleh karena itu, peran pentingnya pemerintah daerah melakukan prinsip good governance salah satunya yaitu penerapan transparansi baik dalam pelaporan keuangan maupun anggaran di era otonomi daerah dapat dilihat dalam dua hal, yaitu sebagai salah satu wujud pertanggungjawaban pemerintah kepada rakyat terkait alokasi dana dari pajak rakyat dan upaya peningkatan manajemen pengelolaan dan penyelenggaraan pemerintahan yang baik dan mengurangi kesempatan praktek kolusi, korupsi dan nepotisme (KKN).

\section{Saran}

Berdasarkan dari penelitian tinjauan literatur ini, untuk menerapkan serta memperbaiki implementasi sistem e-budgeting dalam penganggaran sektor publik maka perlu memperhatikan apa saja faktor-faktor penting yang terkait. Dalam penelitian ini, peneliti menyadari bahwa penelitian ini masih memiliki beberapa keterbatasan. Maka diharapkan untuk penelitian selanjutnya dapat menggunakan metode perhitungan statistik agar lebih menambah keakuratan data untuk mengukur sejauh mana implementasi $e$ - budgeting dalam pengelolaan sektor publik. Selain itu, Pemerintah daerah Provinsi dan Kabupaten/Kota di seluruh indonesia diharapkan dapat menerapkan $e$ budgeting dalam penyusunan anggarannya. Penerapan $e$ budgeting mampu mengatasi anggaran siluman dan modus penyalahgunaan anggaran seperti markup, munculnya program dan kegiatan siluman, manipulasi spesifikasi barang dan penyelewengan realisasi penggunaan anggaran yang mempengaruhi kualitas pelaporan keuangan pemerintah daerah.

\section{DAFTAR PUSTAKA}

Adila, R. N., \& Dahtiah, N. (2020). Evaluasi Penerapan Sistem E-Budgeting dengan Pendekatan Human Organization Technology Fit Model pada Pemerintah Provinsi Jawa Barat. Industrial Research Workshop and National Seminar, 2015, $1-7$.

Alahi, M. E. E., \& Mukhopadhyay, S. C. (2019). Literature Review. In Smart Sensors, Measurement and Instrumentation (hal. 7-41). https://doi.org/10.1007/978-3-030-20095-4_2.

Andhayani, A. (2020). Sistem Informasi Pemerintahan Daerah: E-Budgeting untuk Mewujudkan Akuntabilitas Pemerintah Daerah. 4(9), 183-193.

Bastian, I. (2019). Akuntansi Sektor Publik di Indonesia. In Lingkup Akuntansi Sektor Publik.

Crespo, C., Ripoll, V., Tamarit, C., \& Valverde, R. (2017). Institutional characteristics and managers ' perceptions of accounting information : impact on e-government use and organisational performance. Spanish Journal of Finance and Accounting / Revista Española de Financiación y Contabilidad, $\quad O O(00)$, 1-14. https://doi.org/10.1080/02102412.2017.1416743

Dini, V. L., Saadah, \& Arsalan, S. (2019). Evaluasi Penerapan E-Government Kota Bandung Ditinjau Dari Transparansi Dan Akuntabilitas. Journals of Economics Development Issues (JEDI), 2(2), 2431.

Gamayuni, R. R. (2020). E-Planning and E-Budgeting Implementation : A Qualitative Study in Lampung Province.

Gamayuni, R. R., \& Hendrawaty, E. (2020). E-Planning, E-Budgeting and the Quality of Government Institution Performance Accountability System in Indonesia. Talent Development \& Excellence, 12(1s), 218-225. http://www.iratde.com

Gunawan, D. R. (2016). Penerapan Sistem E-Budgeting Terhadap Transparansi Dan Akuntabilitas Keuangan Publik (Studi Pada Pemerintah Kota Surabaya). Jurnal Akuntansi, 8(1), 72-102.

Julianty, A. F. (2020). Analisis Implementasi E Budgeting Dalam Mendukung Transparansi Pada 
Pemerintah Kota Surakarta. Journal of Politic and Government Studies, 9(4), 149-162.

Juliar, R., \& Dahtiah, N. (2020). Implementasi Kebijakan dan Sistem Pengendalian Manajemen E- Budgeting dalam mewujudkan Good Governance ( Studi Kasus Pada Pemerintah Kota Bandung ). Indonesian Accounting Research Journal, 1(1), 162-172.

Khoirunnisak, R., Arishanti, D., \& Dadeka Vebrianti, D. (2017). Penerapan E-Budgeting Pemerintah Kota Surabaya dalam Mencapai Good Governance. UNEJ e-Proceeding, 2017, 27-28. https://jurnal.unej.ac.id/index.php/prosiding/articl e/view/6715

Lathifah, N., \& Toni Roby Candra Yudha, A. (2018). Rancangan Database E-Budgeting: Upaya Pengendalian Dana Hibah Pemerintah Provinsi Jawa Timur. 1209-1233.

Maryam, N. S. (2016). Mewujudkan Good Governance Melalui Pelayanan Publik. Jurnal Ilmu Politik dan Komunikasi.

Massaro, M., Dumay, J., \& Guthrie, J. (2016). On the shoulders of giants: undertaking a structured literature review in accounting. Accounting, Auditing and Accountability Journal. https://doi.org/10.1108/AAAJ-01-2015-1939

Muflihah, Y., \& Susanto, T. D. (2017). Faktor yang Mempengaruhi Warga dan Pemerintah dalam Adopsi E-Government: Sebuah Ulasan Sistematis. Jurnal Teknologi Informasi dan Ilmu Komputer, $4(4)$, https://doi.org/10.25126/jtiik.201744366

Musfikar, R. (2018). Kendala Dalam Implementasi EGovernment Pada. 2, 48-58.

Nasution, D. A. D., \& Agustina, T. (2019). FaktorFaktor Yang Mempengaruhi Kinerja DaerahKeuangan Pemerintah. 10(1), 101-114.

O Connor, A., Sargeant, J., \& Wood, H. (2017). Systematic reviews. In Veterinary Epidemiology: Fourth Edition (hal. 397-420). https://doi.org/10.1002/9781118280249.ch19.

Oktaviani, R. F., Puspaningtyasfaeni, D., \& Puspitaningtyasfaeni, R. (2019). E-Budgeting for Public Finance Transparency and Accountability. 2, 854-857. https://doi.org/10.35940/ijrte.B1 170.0782S419

Prabowo, T. J. W., Leung, P., \& Guthrie, J. (2018). Reforms in public sector accounting and budgeting in Indonesia (2003-2015): Confusions in implementation. Journal of Public Budgeting, Accounting and Financial Management, 30(1), 221. https://doi.org/10.1108/JPBAFM-03-2018-002

Sagita, N. I., \& Mariana, D. (2017). E-Budgeting: Bandung City Government's Efforts In The Transparency And Efficiency Of Budget
Management. The 2nd Journal of Government and Politics International Conference, 437-446.

Santis, S., Grossi, G., \& Bisogno, M. (2018). Public sector consolidated financial statements : a structured literature review. Journal of Public Budgeting, Accounting \& Financial Management, 30(2), 230-251. https://doi.org/10.1108/JPBAFM02-2018-0017

Santosa, M. H., Maarif, S., Eriyatno, \& Andati, T. (2016). Strategi Sistem Audit Internal Pemerintah dalam rangka Tata Kelola yang Baik. Jurnal Keuangan dan Perbankan, 20(02), 263-373.

Saputra, O. A., Hakim, A., Saleh, C., \& Pratiwi, R. N. (2019). The Implementation of $\boldsymbol{E}$ - Budgeting Policy in Regional Government ( A Case Study in Jakarta Province Province ). 10(3), 75-98. https://doi.org/10.2478/hjbpa

Setyawan, W., \& Gamayuni, R. R. (2020). The Quality of Financial Reporting and Internal Control System before and after the Implementation of Ebudgeting in Indonesia Local Government. Asian Journal of Economics, Business and Accounting, 14(3), 22-31. https://doi.org/10.9734/ajeba/2020/v14i330194

Sipahutar, I. S., \& Sutaryo, S. (2017). Faktor-Faktor Penentu Implementasi E-Goverment Pemerintah Daerah Di Indonesia. Jurnal Riset Akuntansi Dan Keuangan, August 2017, 17.

Sujarweni: 20. (2016). Buku Pengantar Akuntansi. Buku Pengantar Akuntansi.

Sururi, A. (2019). Inovasi Kebijakan Organisasi Sektor Publik Menuju Terwujudnya Good Public Policy Governance. Jurnal Good Governance. https://doi.org/10.32834/gg.v15i1.96

Suryanarayana, T. M. V., \& Mistry, P. B. (2016). Review of Literature. In SpringerBriefs in Applied Sciences and Technology (hal. 27-37). https://doi.org/10.1007/978-981-10-0663-0

Tarigan, A. K. M., Samsura, D. A. A., Sagala, S., \& Pencawan, A. V. M. (2017). Medan City : Development and governance under the decentralisation era. Cities, 71(April), 135-146. https://doi.org/10.1016/j.cities.2017.07.002

Thorne, L., Andiola, L. M., Bedard, J. C., \& Hux, C. T. (2019). Writing a literature review in Behavioural Accounting Research. In The Routledge Companion to Behavioural Accounting Research (hal. https://doi.org/10.4324/9781315710129-30

Wahyuningsih, D., \& Purnomo, E. P. (2020a). Studi Komparasi: Penerapan E-Government di Korea Selatan dan Indonesia. Jurnal Noken: Ilmu-Ilmu Sosial. https://doi.org/10.33506/jn.v5i2.822

Wahyuningsih, D., \& Purnomo, E. P. (2020b). Studi Komparasi: Penerapan E-Government di Korea 
Selatan dan Indonesia. Jurnal Noken: Ilmu-Ilmu Sosial, $5(2)$,

37. https://doi.org/10.33506/jn.v5i2.822

Yuhertiana, I. (2015). Behavioural Public Sector Accounting Research In Indonesia: A Literature Review. Malaysian Accounting Review, 14.

Zhu, M., Sari, A., \& Lee, M. M. (2018). A systematic review of research methods and topics of the empirical MOOC literature (2014-2016). The
Internet and Higher Education. https://doi.org/10.1016/j.iheduc.2018.01.002

Zubaidi, N., Cahyono, D., \& Maharani, A. (2019). Pengaruh Kompetensi Sumber Daya Manusia dan Pemanfaatan Teknologi Informasi terhadap Kualitas Laporan Keuangan. International Journal of Social Science and Business, 3(2), 68-76. https://doi.org/10.37641/jiakes.v8i2.372 